\title{
Cross-Border Cooperation in Europe: The Case of Bihor-Hajdu Bihar Euroregion
}

\author{
Laura Cismaș \\ Faculty of Economy and Business Administration, West University of Timişoara \\ 16 J.H. Pestalozzi St., 300115, Timișoara, Romania \\ Tel: 40-727-918819 E-mail: laura13cismas@yahoo.com \\ Cosmin Sabău \\ Faculty of Economy and Business Administration, West University of Timişoara \\ 16 J.H. Pestalozzi St., 300115, Timișoara, Romania \\ Tel: 40-745-380226 E-mail: cosminsab@yahoo.com
}

$\begin{array}{ll}\text { Received: December 5, } 2011 & \text { Accepted: January 11, } 2012 \quad \text { Published: March 1, } 2012 \\ \text { doi:10.5539/ibr.v5n3p91 } & \text { URL: http://dx.doi.org/10.5539/ibr.v5n3p91 }\end{array}$

\begin{abstract}
Cross-border cooperation has become, in the recent years, one of the basic pillars of the elimination process of development disparities between regions. The available economic and social datas suggests an important development of the area border especially after 2002, when Hajdu-Bihar and Bihor founded the Bihor-Hajdu Bihar Euroregion. Regional policy has also contributed through several cross-border projects, financed from European funds and for the future there are premises to obtain a dynamic of regional economies in the two areas with increased investments in priority areas (infrastructure, environment business, tourism, education, health, etc.).
\end{abstract}

Keywords: Cross-border cooperation, Euroregion, Territorial cooperation, County, Regional policy

\section{Introduction}

Since cross-border cooperation is a priority objective of EU regional policy for the current financial programming exercise, in the first section of the research is allocated a space meant to define this European policy. In plus, its role has increased in the last years, with the European Union's enlargement to 27 states.

The fact that there are inequalities in economic development between countries or even within the same country is a reality of all time, more or less tolerated, but never fully accepted and always subject of explanations, polemics and disputes. At the European level, in present time, reducing the development disparities between countries and regions, the so-called regional disparities represent the regional policy's assumed objective through which it promotes economic convergence within the European Union.

It is also necessary to know the involvement of the policy in question in the nearby territories situated in neighbor states. Besides this, in the context of the growing importance of cross-border cooperation at a European level, the present paper proposes itself to bring forward a short analysis of the concepts of territorial and cross-border cooperation (one of the three forms of territorial cooperation) in its second section.

The investigation methodology used combines analysis and synthesis, the regulatory and explorative approach, quantitative analysis and qualitative assessments. In other words, in the present research we have used modern methods of investigation (Internet documentation, international databases access, direct documentation from specialized papers, etc.); we added statistical methods for data interpretation (schedules) and the method used for calculating certain socio-economical indicators from Bihor and Hajdu-Bihar counties.

Therefore the research methods were based on the study of theoretical elements as a result of reading important articles from the regional development area and the analysis of several case studies. In this way, we could interpret the information obtained.

\section{What is the Regional Policy?}

The reality in today's Europe shows that differences in development between Member States of the European 
Community are quite obvious. Moreover, imbalances are large also within countries, living standards of citizens being different from one area to another. In this context, regional policy has played, plays and will play an important role to mitigate and even to eliminate these gaps. Therefore, this first section provides some clarification on the definition of this type of European policy. Thus, in the paper entitled "Regional policy and the coordination of structural instruments", it is estimated that regional policy represents "in the first place the solidarity between Member States; it is designed to help the most disadvantaged regions. Regional policy is tangible; its results are visible for EU citizens, who benefit directly from assistance in a job search and adapting to labor market changes, especially through training courses."'(Pascal et al, 2004)

The same authors state that regional policy does nothing but lead to improving the lives of people living in less developed regions, by increasing the funds that local authorities benefit of in order to create new infrastructure and help companies become more competitive (eg. highways, airports, railway networks, all were built with structural funds, SMEs have been established and helped to operate in decline areas or the information society has penetrated the most remote rural areas) (Pascal et al, 2004).

Another definition is given by Dorin Dolghi in his paper entitled Region and Regionalization in the EU in which he considers that regional policy is "a set of measures adopted at Community level to support the less developed regions, aiming to create or to restore a relative balance in the economic activities, living standards, population distribution" (Dolghi, 2004). Petre Prisecaru in his paper entitled "Common EU Policies", quoting Michel Barnier, says: common regional policy is the only tool designed expressly for disparities, while in the same time being a very specific tool, which involves a transfer of resources among member countries through the EU budget (Prisecaru, 2004).

The European Commission, the European Union's executive body, tried to give a definition to the term of regional policy, concluding that regional development policy seeks to reduce the visible effects on the gap between the development levels of different regions. Also, this type of policy plays an important role in the financial support of projects aimed to the development of regions, cities and increasing living standard of their inhabitants. Therefore, the main goal is to create a potential for regions so that they contribute to the growth and development of economic competitiveness. (Note 2)

Based on the above statements, regional policy can be defined as a set of means (tools) needed to eliminate the national and regional development disparities. This will be achieved by stimulating cooperation between regions and interregional, competitive environment creation and development, financial support (through European funds) of less developed regions, stimulating the investments in problematic areas through an appropriate fiscal policy, increasing skilled human resources and so on.

Thus, in addition to the above definition, we can say that EU regional development policy gives an impulse in the recovery of regional differences within the European Community, especially that from the signing of the Single European Act and the Maastricht Treaty, the European Union has set itself the task to reduce regional development disparities and also to prevent in a certain extent the backwardness of the less developed areas.

\section{Territorial Cohesion and Cross-Border Cooperation in the View of EU}

As the authoress Alice Engl states, the development of an even greater number of cross-border projects, as well as the occurrence of cross-border territories, were based on three products created by the European Union: the euro currency, the unique internal market and the Schengen agreement (Engl, 2009).

Thereby, the areas within borders turned into areas of collaboration between economical, social and political systems belonging to different countries, in which human, natural and financial resources can be used in common by the inhabitants of those settlements (Engl, 2009).

An aspect worth being mentioned is that an ever-growing interest in territorial cooperation on the part of national, regional, local and international actors had been observed in the recent years.

This idea is enhanced by the fact that, as EU has to economically deal with the challenges of the world economy, the continent cannot remain isolated in relation to what happens outside its borders (Gambert \& Jann, 2011).

An extremely important remark is made by Jirka Zapletal, who noticed that integration brought into discussion another aspect, namely territorial cooperation within European areals, this becoming one of the Union's objectives according to the Treaty of Lisbon signed in 2000 (Zapletal, 2010).

Thus, territorial cooperation supports the achievement of national cohesion, the infrastructure and communications, cultural changes, as well as collaborations in the sphere of tourism between: territories situated on both sides of the borders, regions and nations (Engl, 2009). 
In order to encourage territorial cooperation, the European Grouping of Territorial Cooperation (EGTC) had been created at the European level, having the purpose of surpassing the difficulties regarding territorial cooperation by organizing an instrument of cooperation at a community level (INTERREG) (Sykes, 2006).

Territorial cooperation is encountered under different forms (that is, cross-border, interregional, transnational). This classification is made according to the needs of regional and local authorities involved and the competences these authorities have in proportion to the national ones (Engl, 2009).

Because territorial cohesion as objective pursued by the regional policy is also achieved by cross-border cooperation, this form of cooperation is emphasized in the following lines, thus making an affinity with the title of the present paper.

The Old Continent, apart from its expansive culture and the common history of nations also comprises a wide range of frontiers (borders). Most states which originated many years ago still exist today, passing through an ample process of transformations during the $19^{\text {th }}$ and $20^{\text {th }}$ centuries, each of them coming to benefit by a certain level of development nowadays. Yet, a few of them can stand on a long age, as the case of the Portuguese-Spanish frontier is (the most ancient territorial frontier in Europe) (Sykes, 2006).

At present, cooperation between territories with natural frontiers, directly adjacent, has an old tradition on the European continent. Even so, in the case of states like Spain, Portugal and Greece, cross-border cooperation began only in the ' 80 s, due to political changes, switching over to democratic systems and obtaining the quality of member of the European Union by these countries. For countries of Central and Eastern Europe, this process started after 1989 (Gambert \& Jann, 2011).

Even from the '50s, at a short interval after the Second World War, the experts of a significant number of European regions disputed on eliminating the frontiers and the possibilities of cross-border cooperation.

What was at the basis of this meeting was the need to increase the standard of living, to allow the existence of a durable peace on the Continent, and to delete the frontier obstacles, the restrictions and other elements that caused the separation of people and authorities from regions with neighboring boundaries (Ghid 2000 Politici Regionale).

At the end of the Second World War, the inhabitants from different borderlands noticed that, in order to have a standard of living equal to the one from the central part of the country, it is necessary to diminish or even to eliminate the negative effects the border had. But they realized this was not possible especially due to the lack of a law-marking framework. Consequently, they laid the foundation of some communal and regional associations situated on both sides of the frontier, which aimed at streamlining cooperation across the borders (Ghid 2000 Politici Regionale).

Starting with the '70s, cross-border regions set up the Association of European Border Regions (AEBR), in 1971. This organism maintained a tight relationship of collaboration with the Council of Europe, the European Parliament and the European Commission. In this way, the network of border and cross-border areas turned into a determinant force for streamlining cross-border cooperation in all these territories on the Continent, contributing to both the activation of European integration and the implementation and development of European programs of assistance for border areals in the entire Europe (Ghid 2000 Politici Regionale).

For this part of Central and Eastern Europe, this form of territorial (cross-border) cooperation began to manifest itself only after 1990 with not a little moderation on the part of the states involved, as these boundaries had been impervious in the past. In this context, collaboration had been carefully prepared, and people had to be made aware of the fact that they still belonged to a common history and they had to look towards a common future in the continental space (Ghid 2000 Politici Regionale).

The bonds existing between two or more local and regional adjacent entities which are in different but neighboring countries represent cross-border cooperation. Collaborations of this kind can be short-dated (for example, for a single project) or on a permanent term-indeterminate (in order to solve some complex problems) (Engl, 2011).

We encounter the euroregion as form of permanent cross-border cooperation, it being an institution implying private or public participants, which establishes cross-border affinities between national, local, and regional organisms. Eurodistricts and working communities can be enumerated as forms of cross-border cooperation as well.

Territorial cooperation between areas placed on both sides of the border give the frontier regions the possibility to develop much more rapidly and to achieve territorial cohesion by capitalizing on the EU support of the Council of Europe (Engl, 2011).

\section{The History of the Euroregion}

The first association between the two neighboring border counties took place in 1997 within other structure of 
cross-border cooperation, of much greater dimensions: the Carpatica Euroregion, which includes administrative-territorial units from five countries.

In order for the cooperation to activate much better between the counties and because the Carpatica euroregion used to have a population which outnumbered the inhabitants of some associated states (Hungary, Slovakia), the formation of some smaller euroregions took place, subsequent to its foundation, as the case of Bihor-Hajdu Bihar euroregion is (Suli Zakar, 2007).

The existing premise in 2002, along with the foundation proper of the euroregion, when the border between Romania and Hungary symbolically disappeared once the two countries joined the EU, which already happened in 2007, and respectively in 2004, represented an important factor that underlay the accomplishment of this euroregion. Thereby, the starting point for the decision of associating the two counties, Bihor and Hajdu-Bihar, into an organization of cross-border cooperation, was the importance the local authorities granted to the economical affinities which started to develop between entities situated on both sides of the boundary. Apart from this aspect, they wanted the two county seats, Oradea and Debrecen, to collaborate within a common program which pointed the development of the border area (Suli Zakar, 2007).

\section{A Comparative Analysis of Bihor and Hajdu-Bihar Counties from an Economical Point of View}

\subsection{A Short Presentation of the Two Counties}

Bihor County lies at the North-West border of Romania, having a surface of $7544 \mathrm{~km}^{2}$, while Hajdu-Bihar lies at the North-East border of Hungary, with a surface of $6211 \mathrm{~km}^{2}$. The two counties do not have a homogenous structure, neither regarding their forms of relief, nor from the viewpoint of the other natural resources (lands, distributed in categories of use and fertility, deposits of raw materials etc.). Nevertheless, they somehow find themselves propelled to establish new ways of cooperation due to the challenges experienced by the inhabitants living on both the Romanian and Hungarian border. Moreover, the differences of resources make it possible and somehow necessary for a certain economical cooperation between Bihor and Hajdu-Bihar.

\subsection{Resources of Employment}

Resources of employment are one of the fundamental resources necessary for a good economical evolution in conditions of efficiency, alongside technical facilities, sometimes in certain situations the latter being even more important than the former.

Analyzing the data related to the stable population, as seen in Table 1 one notices that Bihor County occupies an adequate place, but is confronted, even if with a slighter intensity than Hajdu-Bihar, with the phenomenon of depopulation, a consequence of the demographic crisis happening in all the European area. (Note1, Note2)

The most derogatory value of this variable was registered in 2006 in Hajdu-Bihar County, and the most favorable one in 2001 in Bihor County, the tendencies in the two counties being inimical.

As for the number of unemployed persons, as seen in Table 2, a certain increase of them can be noticed, after a relative decrease, the tendency of increment occurring in 2007 in Hajdu-Bihar and from 2008 in Bihor County. The most derogatory value of this variable is registered in 2010 in Hajdu-Bihar County and the most favourable one in Bihor County in 2001. Analyzing the available data regarding the number of employees, one can notice the most derogatory situation in 2001 in Hajdu Bihar County, and the most favourable value of this variable is registered in 2008 in Bihor County. (Note1, Note2)

\subsection{The Business Environment}

In order to characterize the state and the dynamics of the business environment, only the indicator of registered companies could be used, mentioning the fact that the business environment is a reality and a much too complex concept to be expressable by a single indicator. Nevertheless, the analysis entails the need of simplification, and the data likely to be obtained under structured and comparable forms are very few.

Analyzing the data referring to the number of companies registered, as seen in Table 3, it appears that the most derogatory situation is in 2005 in Bihor County, and the most favourable value of this variable is registered in Hajdu-Bihar County in 2010. The basic tendency is of increase in both counties.

At the same time, in order to appreciate the economical life, the indicator GDP, as seen in Table 4, was used, expressed in millions of USA dollars.

Thus, if the values of the indicator previously mentioned are interpreted, it can be noticed that the most derogatory situation is at the level of 2004 in Bihor County, and the most favourable one is at the level of 2008 within Hajdu-Bihar County. It is interesting that, witnessing the evolution of these values, the differences tend to shade 
away through the time, the values of the indicators heading for an equalization at the level of 2008, which denotes a refreshing, a certain progress of the economical activity in Bihor County, in a more increased rhythm than in Hajdu-Bihar County, phenomenon that leads to the reduction of these dissimilarities.

\subsection{The Educational Environment and Health}

If the data referring to the number of kindergartens and schools of all degrees, as seen in Table 5 in pre-university are interpreted, then the most derogatory situation registered is noticed in 2008 in Bihor County, and the most favorable value of this variable is still recorded in Hajdu-Bihar County in 2000.

If the evolution of this indicator in Hajdu-Bihar County is relatively normal, without too great variations, the data suggest a real catastrophy in what concerns Bihor County.

The disastrous situation Bihor County got up to at this chapter has as a consequence the amalgamation of more educational institutions, especially in the rural area and concurrently the significant decrease of the number of children after 1990, fact which can be found in the national demographic reduction.

By analyzing the data which refer to the number of hospital beds available within the public sanitary units, as seen in Table 6, the most derogatory situation is detected in 2009 in Bihor County, and the most favorable value of this variable is recorded in Hajdu-Bihar County in 2002. The salient differences between the two counties can be noticed.

Interpretation of data referring to the number of beds used in the public sanitary units, as seen in Table 7, leads us to the conclusion that the most derogatory situation is in 2008 in Hajdu-Bihar County, and the most favorable value of this variable is obtained in 2000 at the level of Bihor County. Still, the favorable or derogatory value of this variable is not certain, it might have as cause either a better health condition of the population in Hajdu-Bihar County in what concerns the diseases which need warding or another facility or vision of the specialized authorities.

\subsection{Tourism}

Analyzing the values of data referring to the total number of tourists arriving in units of public accommodation, as seen in Table 8 it is noticed that the most derogatory situation can be encountered at the level of 2009 in Bihor County, and the most favorable at the level of 2007 in Hajdu-Bihar County. The differences are pointedly favorable to the neighboring county.

In what concerns the number of foreign tourists' arrivals, the dissimilarities between the two counties are even more pronounced, the number of sojourns/passing the nights of the foreign tourists are considerably favorable to Hajdu-Bihar County.

Analyzing the values of data referring to the total number of tourists nights spent in units of public accommodation, as seen in Table 9, it results that the most derogatory situation is encountered at the level of 2009 in Bihor County, and the most favorable situation is at the level of 2007 in Hajdu-Bihar County. The differences are again pointedly favorable to the neighboring county, in some cases even three times better. Classifying the tourists from the two counties according to the provenient countries is again advantageous for Hajdu-Bihar County.

Analyzing the data related to the total number of foreign tourists' passing the nights in units of public accommodation, as seen in Table 10, one can notice that the most derogatory situation is at the level of 2009 in Bihor county, and the most favorable one at the level of 2007 in Hajdu-Bihar county. The differences are again pointedly favorable to the Hungarian county, but without being so great in the case of the former situation presented in this subchapter, the greater number of tourists' passing the nights somehow compensating the dissimilarities in the number of arrivals.

In all the cases previously presented and interpreted, the statistical bonitierung method was used, the results obtained being after the estimations done by the authors.

The analysis of a single table or of a single chart can suggest certain punctual conclusions to us, consistent in the case of the respective indicator.

Therefore, in order to actually have an overall image, the statistical bonitierung method can be applied, in which the value of each indicator of performance (those having the meaning of the more, the better) is assigned a draft obtained by dividing it to the minimum value from the table, the result being multiplied by 100 .

For the indicators having a reversed variation (those with the meaning of the less, the better), as is the indicator of the number of unemployed, the process is the same, with the discrepancy that instead of the minimum value, the maximum one is used, and for the estimation of the compound indicator, the values of the factors/coefficients obtained do not add up to the total but are substracted. 
Finally, the values of the drafts add up or are substracted according to the case, and are divided to the total number of indicators per years.

A set of individual values issues from it, offering a clearer and a more rapid image both over the economical potential and the level of the development of the two counties than the individual analysis of the tabular data or those represented under the form of charts.

The weak point of the method is that it assigns the same importance to each indicator, but the strong points are on the one hand, the simplicity of the method, and then, on the other hand, it allows characterizing the state of the two counties according to all the indicators both individually and simultaneously.

As the interpretation of data presented under a tabular and graphic form is encountered and acknowledged with more ease by the users already accustomed to these presentations, one insisted upon the description of the data statistically retrieved both at the level of tables containing individual indicators and as analysis of the compound indicator.

One can notice the somehow contradictory influence of the factors taken into account upon the compound indicator. The cause of the apparent equalization in the level of the development of the two counties consists in repeating the figure 100 of the bonitierung draft where there were no initial available data for the respective years, which affects the general volume of corresponding indicators and their apparent dynamics. More exactly, in the first variant of bonitierung method, in which there are missing data for the indicators analyzed, the neuter value of 100 was employed, hence the results seeming much too identical.

Thereby, in the final variant, the value of 100 had been eliminated and the existing values of the indicators had been taken into consideration. Thus, the general table of bonitierung method was refigured by leaving the columns without data blank. Even if the final tendency of equalization is present, the dynamics in the final form of bonitierung method is closer to reality.

\section{The Situation of Cross-Border Cooperation in Bihor-Hajdu Bihar Euroregion}

The data referring to cross-border cooperation at the level of Bihor-Hajdu Bihar euroregion had been made available by the Regional Office of Cross-border Cooperation Oradea (BRECO).

Within the Phare Program CBC 2004 Romania-Hungary, as seen in Table (11), a number of ten projects had been effectuated and finished, having a total value of 1.807.523,1 euros, out of which the Phare part was of 1.355.642,3 euros, the national financing share of Romanian authorities being of 451.880,8 euros, and the co-financing of the beneficiary was of 263.982,9 euros.

Within the Phare Program CBC Romania-Hungary, a number of 39 projects had been completed during 2004-2006, having a total value of 6.538.844 euros, out of which the Phare part was of 4.515.114 euros, the Romanian national share of financing being of 1.423 .513 euros, and the co-financing of the beneficiary was of 815.480 euros.

\section{The Analysis of the Effects of the Completed Cross-Border Projects}

It is difficult to quantify the influence of cross-border projects upon economical life, because on the one hand the effects are not many times immediate. Their results are likely to be felt after a certain period of time and to manifest themselves on long time frames, possibly decades (for example, the achievement of a purification station).

On the other hand, there are two categories of possible effects; first, it is the local one, where the project is carried out, and which begins to assert from the very time of effectuating the investment. More exactly, it is about the work force employed locally, the respective employees have higher salaries, thus the consumption will increase both in volume and structure, and they can pay their taxes and local impositions. Thereby, the local city halls have higher incomes, being able to function at better parameters. The second category of effects includes those belonging to the level of the county and implicit of the euroregion, as both the welfare and the misery propagate around.

In the present case, that is the euroregion Bihor-Hajdu Bihar, due to the insufficiency of the data gathered and their minimalist character, it is very difficult to analyze the effects of the regional cross-border projects.

All the more so as to make such a study, it would be ideal to follow the effects upon the localities where the respective projects are accomplished and not only the economical ones.

Of course, any completed project has an economical component, but this is not the only one. Sometimes the administrative part, of environmental protection or strictly regarding the specificity of the local community, the preservation of certain traditional crafts, become much more important than the economical aspect strictly. All these elements previously mentioned need both great time resources and people. But, in spite of them, it can represent a research topic for the future, which can extend the actual stage of the present research. 
Precisely from the reasons presented above, even if the establishment of a compound indicator was initially expected by which to eventually measure the effect of these cross-border projects upon the economy of the euroregion, it was concluded that it was difficult to achieve. The bonitierung method could not be applied because of the very few available data from the statistical organizations, data which are prospected for under different forms, structure and unity of measurement. This makes it difficult to find a set of common data to be pursued and available on common periods within intervals as long as possible

\section{Conclusions}

It can be said that, regarding the socio-economical level of the two counties composing the euroregion Bihor-Hajdu Bihar, in the recent years the Hungarian county has had an advantage. If the entire analyzed period (2000-2010) is being prospected for, one can notice that, in the first interval, this county has succeeded into gaining on the inequality unto Bihor County, and, on the whole, it can be said that the euroregion in question is characterized by a certain uniformity of the economical-social life.

Cross-border cooperation plays an important role in the development of Bihor-Hajdu Bihar euroregion, the local authorities from the two counties intending to significantly enhance the number of bilateral projects. At the same time, the economical potential of the area is an increased one, and the key to a balanced development of the border territory will be to attract important sums of European money by means of structural funds.

This result (catching up the differences) can be achieved by investing significant amounts of money in sectors of regional economy capable of producing plus value.

Also, it should be noted that there isn't a general indicator by which to judge the effect of European money in the territory, specifically in the national and regional economies. In other words, the European Union directs the money to member states, but then it doesn't have a record of their impact on the economic development of those countries. Therefore, for the future it would require a careful analysis of this issue at the European level in order to identify the result of using the European funds.

\section{References}

Cismaş, L., \& Sabău, C. (2011). The evolution of the socio-economical profile and cross-border cooperation in Bihor-Hajdu Bihar Euroregion. Recent Researches in Tourism and Economic Development, 160-165.

Dolghi, D. (2004). Regiune şi Regionalizare în Uniunea Europeană, 75.

Engl, A. (2009). Territorial cooperation in Europe: Coordinated strategy or lost in confusion?. Institute of Governance Studies, 3.

Engl, A. (2011). Future perspectives on territorial cooperation in Europe: The EC regulation on a European grouping of territorial cooperation and the Planned Council of Europe Third Protocol to the Madrid Outline Convention Concern Euroregional Co-operation Groupings, European Diversity and Autonomy Papers.

Gambert, N., \& Jann, R. (2011). European Cohesion Policy and Territorial Cooperation. Neighbouring Countries: Towards Deeper Coordination?. European Journal of Spatial Development.

Pascal, I., Vlad, M., Deaconu, Ş., \& Vrabie, C. (2004). Politica regională şi coordonarea instrumentelor structurale, Centrul de Resurse Juridice.

Pascariu, G., Lhomel, E., Stănculescu, M., Jula, D., \& Luțaş, M. (2002). Impactul politicii de coeziune socială asupra dezvoltării economico-sociale la nivel regional în România, Pre-Accession Impact Studies 8.

Prisecaru, P. (2004). Politici Comune ale UE, Editura Economică, 75.

Sykes, O. (2006). The Evolving Context for European Territorial Co-Operation, Town and Country Planning, 288.

Suli Zakar, I. (2007). A hatarokes a Hataron Antyulo (CBC) Kapesolatok, 99.

Zapletal, J. (2010). The European Grouping of Territorial Coperation-EGTC: A New Tool Facilitating Cross-Border Cooperation and Governance Quaestiones Geographicae, 15.

AEBR's Ghid 2000 Politici Regionale, elaborated by AEBR (section C2), 5-6.

\section{Notes}

Note 1. http://portal.ksh.hu/pls/ksh/docs/eng/xstadat/xstadat_annual/i_qlf022.htm.

Note 2. http://ec.europa.eu/regional_policy. 
Table 1. Stable Population (in Thousands)

\begin{tabular}{ccccccc}
\hline Year & 2001 & 2002 & 2003 & 2004 & 2005 & 2006 \\
\hline Hajdu Bihar County & 553.264 & 552.478 & 551.837 & 550.265 & 549.372 & 547.357 \\
Bihor County & 619.529 & 603.743 & 602.206 & 598.381 & 596.670 & 595.448 \\
\hline
\end{tabular}

Source: The online data base TEMPO ONLINE, Romania's National Institute of Statistics.

http://portal.ksh.hu/pls/ksh/docs/eng/xstadat/xstadat_annual/i_qlf022.html, accessed in 15.05.2011

Table 2. Number of Unemployed Persons (in Thousands)

\begin{tabular}{cccccccccccc}
\hline & 2000 & 2001 & 2002 & 2003 & 2004 & 2005 & 2006 & 2007 & 2008 & 2009 & 2010 \\
\hline Hajdu Bihar & 14.5 & 13.1 & 13.4 & 12.5 & 11.9 & 17.6 & 20.0 & 16.3 & 18.4 & 22.7 & 27.9 \\
Bihor & 16.5 & 10.1 & 14.9 & 10.5 & 9.3 & 12.3 & 12.8 & 11.5 & 13.9 & 23.3 & 23.3 \\
\hline
\end{tabular}

Source:The online data base TEMPO ONLINE, Romania's National Institute of Statistics.

http://portal.ksh.hu/pls/ksh/docs/eng/xstadat/xstadat_annual/i_qlf022.htm, accessed in 15.05.2011

Table 3. Number of Companies Registered (in Thousands)

\begin{tabular}{ccccccc}
\hline Year & 2005 & 2006 & 2007 & 2008 & 2009 & 2010 \\
\hline Hajdu Bihar & 18301 & 18775 & 19340 & 20422 & 21290 & 22130 \\
Bihor & 15168 & 16118 & 17750 & 18850 & 18850 & 18850 \\
\hline
\end{tabular}

Source: The online data base TEMPO ONLINE, Romania's National Institute of Statistics.

http://portal.ksh.hu/pls/ksh/docs/eng/xstadat/xstadat_annual/i_qlf022.htm, accessed in 15.05.2011

Table 4. GDP (Millions US Dollars)

\begin{tabular}{ccccccc}
\hline Year & 2004 & 2005 & 2006 & 2007 & 2008 & Average \\
\hline Hajdu Bihar & 4218.48 & 4416.21 & 4390.93 & 5295.36 & 5966.13 & 4047.9 \\
Bihor & 2255.37 & 2751.68 & 3372.03 & 4708.57 & 5456.94 & 3090.8 \\
\hline
\end{tabular}

Table 5. Number of Kindergartens and Schools of All Degrees

\begin{tabular}{ccccccccccc}
\hline Year & 2000 & 2001 & 2002 & 2003 & 2004 & 2005 & 2006 & 2007 & 2008 & 2009 \\
\hline Hajdu Bihar & 509 & 521 & 515 & 517 & 517 & 526 & 520 & 520 & 521 & 518 \\
Bihor & 1014 & 1005 & 1001 & 349 & 348 & 345 & 221 & 225 & 219 & 228 \\
\hline
\end{tabular}

Source: The online data base TEMPO ONLINE, Romania's National Institute of Statistics.

http://portal.ksh.hu/pls/ksh/docs/eng/xstadat/xstadat_annual/i_qlf022.htm, consultat la 15.05.2011

Table 6. Number of Hospital Beds Available within the Public Sanitary Units

\begin{tabular}{ccccccccccc}
\hline Year & 2000 & 2001 & 2002 & 2003 & 2004 & 2005 & 2006 & 2007 & 2008 & 2009 \\
\hline Hajdu Bihar & 15521 & 14940 & 17969 & 16556 & 16076 & 17330 & 15573 & 16268 & 16580 & 15750 \\
Bihor & 10472 & 10442 & 10442 & 10475 & 10591 & 10455 & 10552 & 10126 & 9984 & 9746 \\
\hline
\end{tabular}

Source: The online data base TEMPO ONLINE, Romania's National Institute of Statistics.

http://portal.ksh.hu/pls/ksh/docs/eng/xstadat/xstadat_annual/i_qlf022.htm, consultat la 15.05.2011

Table 7. Number of Beds Used in the Public Sanitary Units

\begin{tabular}{ccccccccccc}
\hline Year & 2000 & 2001 & 2002 & 2003 & 2004 & 2005 & 2006 & 2007 & 2008 & 2009 \\
\hline Hajdu Bihar & 4292 & 4340 & 4281 & 4379 & 4290 & 4285 & 4290 & 3738 & 3713 & 3738 \\
Bihor & 5659 & 5609 & 5556 & 4528 & 4613 & 4566 & 4274 & 4250 & 4272 & 4253 \\
\hline
\end{tabular}

Source: The online data base TEMPO ONLINE, Romania's National Institute of Statistics.

http://portal.ksh.hu/pls/ksh/docs/eng/xstadat/xstadat_annual/i_qlf022.htm, consultat la 15.05.2011

Table 8. Total Number of Tourists Arrival in Units of Public Accommodation

\begin{tabular}{cccccc}
\hline Year & 2005 & 2006 & 2007 & 2008 & 2009 \\
\hline Hajdu Bihar & 299730 & 369451 & 402291 & 395006 & 359138 \\
Bihor & 216019 & 212194 & 227334 & 228235 & 201234 \\
\hline
\end{tabular}

Source: The online data base TEMPO ONLINE, Romania's National Institute of Statistics.

http://portal.ksh.hu/pls/ksh/docs/eng/xstadat/xstadat_annual/i_qlf022.htm, consultat la 15.05.2011 
Table 9. Total Number of Tourists Nights Spent in Units of Public Accommodation

\begin{tabular}{cccccc}
\hline Year & 2005 & 2006 & 2007 & 2008 & 2009 \\
\hline Hajdu Bihar & 1073564 & 1304289 & 1333334 & 1260285 & 1128619 \\
Bihor & 1131164 & 1145183 & 1139245 & 1128159 & 998638 \\
\hline
\end{tabular}

Source: The online data base TEMPO ONLINE, Romania's National Institute of Statistics.

http://portal.ksh.hu/pls/ksh/docs/eng/xstadat/xstadat_annual/i_qlf022.htm, consultat la 15.05.2011

Table 10. Total Number of Foreign Tourists' Passing the Nights in Units of Public Accommodation

\begin{tabular}{cccccc}
\hline Year & 2005 & 2006 & 2007 & 2008 & 2009 \\
\hline Hajdu Bihar & 407915 & 431100 & 452935 & 435308 & 373784 \\
Bihor & 82150 & 82150 & 100679 & 78368 & 73958 \\
\hline
\end{tabular}

Source: The online data base TEMPO ONLINE, Romania's National Institute of Statistics.

http://portal.ksh.hu/pls/ksh/docs/eng/xstadat/xstadat_annual/i_qlf022.htm, consultat la 15.05.2011

Table 11. The Finance of Phare CBC Program 2004 Romania-Hungary

\begin{tabular}{cccccc}
\hline Total EURO & Phare EURO & $\begin{array}{c}\text { Național } \\
\text { EURO }\end{array}$ & $\begin{array}{c}\text { Co-finance Beneficiary } \\
\text { EURO }\end{array}$ & Field & $\begin{array}{c}\text { Total number of } \\
\text { projects }\end{array}$ \\
\hline 32.070 & $24.052,5$ & $8.017,5$ & 4.140 & Administration & 2 \\
841.550 & $631.162,5$ & $210.387,5$ & 97.950 & Infrastructure & 2 \\
410.047 & $307.535,25$ & $102.511,75$ & 46.744 & Education & 2 \\
491.412 & 368.559 & 122.853 & 111.544 & Business Environment & 3 \\
$324.44,105$ & $243.33,075$ & $8.111,03$ & $3.604,9$ & Environment & 1 \\
$1.807 .523,105$ & $1.355 .642,325$ & $451.880,78$ & $263.982,9$ & Grand Total & 10 \\
\hline
\end{tabular}

Source: BRECO Oradea. 